\title{
Cofactor Requirements of Constitutive Aromatic L-Amino Acid Decarboxylase from Micrococcus percitreus
}

\author{
Hidetsugu NaKazawa, ${ }^{*}$ Hidehiko KumagaI** \\ and Hideaki YAMADA \\ Department of Agricultural Chemistry, Faculty of Agriculture, \\ Kyoto University, Kyoto 606, Japan \\ *The Central Research Laboratories, Ajinomoto, Co., Inc., \\ Kawasaki 210, Japan \\ **Department of Food Science and Technology, Faculty of \\ Agriculture, Kyoto University, Kyoto 606, Japan
}

Received January 24, 1983

\begin{abstract}
Crystalline aromatic L-amino acid decarboxylase from Micrococcus percitreus is inactive in the absence of pyridoxal phosphate (PLP). The inactive form of the enzyme shows absorption at $340 \mathrm{~nm}$ and contains one mol of PLP per mol of enzyme. Binding of PLP to the inactive form is accompanied by a pronounced increase in absorbance at $415 \mathrm{~nm}$. The amount of PLP that binds to this holoenzyme is $2 \mathrm{~mol} \mathrm{per} \mathrm{mol} \mathrm{of} \mathrm{enzyme.} \mathrm{The} \mathrm{inactive} \mathrm{half-resolved} \mathrm{form,} \mathrm{i.e.}$ semiapoenzyme, is obtained again by dialysis of the holoenzyme against phosphate buffer. When the semiapoenzyme is dialyzed against phosphate buffer containing 3,4-dihydroxyphenylL-alanine, it loses the absorption at $340 \mathrm{~nm}$ with the loss of PLP. This apoenzyme regains the activity and absorption at $340 \mathrm{~nm}$ and $415 \mathrm{~nm}$ on association with PLP.
\end{abstract}

In the previous papers, ${ }^{1,2)}$ we described a procedure for obtaining a crystalline constitutive aromatic L-amino acid decarboxylase from the cells of M. percitreus (AJ 1065) and also reported some of its properties.

The crystalline preparation shows negligible activity in the absence of PLP. On association with PLP the enzyme shows pronounced absorption peaks at 340 and $415 \mathrm{~nm}$. These peaks are attributable to PLP bound to the apoenzyme in a catalytically active form. This paper deals with studies on the cofactor requirements of the constitutive aromatic Lamino acid decarboxylase from $M$. percitreus.

\section{MATERIALS AND METHODS}

Materials. Crystalline aromatic L-amino acid decarboxylase was prepared from the cell extract of $M$. percitreus (AJ 1065) grown on a medium containing $0.5 \%$ of yeast extract, $3 \%$ of soybean hydrolyzate, $0.5 \%$ of pepton, $0.5 \%$ of glycerol, $0.1 \%$ of $\mathrm{KH}_{2} \mathrm{PO}_{4}, 0.1 \%$ of $\mathrm{MgSO}_{4} \cdot 7 \mathrm{H}_{2} \mathrm{O}, 0.001 \%$ of $\mathrm{FeSO}_{4} \cdot 7 \mathrm{H}_{2} \mathrm{O}, 0.01 \%$ of $\mathrm{MnSO}_{4} \cdot 5 \mathrm{H}_{2} \mathrm{O}$ and $0.01 \%$ of antifoam AF emulsion, as previously described. ${ }^{1)}$ PLP was kindly provided by
Dainippon Pharmaceutical Company, Ltd., Osaka. Other chemicals used in this work were commercial products.

Enzyme assay. Aromatic L-amino acid decarboxylase activity was determined by measuring the amount of tryptamine formed from L-tryptophan under the conditions described in the previous paper. ${ }^{1)}$ One unit of activity was defined as the amount of enzyme which catalyzed the formation of $1 \mu \mathrm{mol}$ of tryptamine per min under the standard assay conditions. Specific activity was expressed as units per $\mathrm{mg}$ of protein.

Protein determination. Protein was determined colorimetrically by the method of Lowry et al. ${ }^{3)}$ with the apoenzyme as standard.

Tryptamine and PLP determinations. Tryptamine was determined spectrophotometrically by measuring the absorbance at $580 \mathrm{~nm}$, according to the method of Kupfer and Atkinson with a slight modification, as previously described.2) PLP was determined by fluorometric spectrophotometry according to the method of Adams. ${ }^{4)}$

Preparation of apoaromatic L-amino acid decarboxylase. Crystalline aromatic L-amino acid decarboxylase was dissolved in a minimum amount of $0.05 \mathrm{M}$ potassium phosphate buffer, $\mathrm{pH} 7.0$, containing $10^{-3} \mathrm{M}$ 
dithiothreitol, $10^{-4} \mathrm{M}$ EDTA and $0.02 \mathrm{~m}$ 3,4-dihydroxyphenyl-L-alanine, and dialyzed overnight at $5^{\circ} \mathrm{C}$ against the same buffer. To remove excess PLP and 3,4dihydroxyphenyl-L-alanine the dialyzed enzyme solution was passed through a column $(1 \times 10 \mathrm{~cm})$ of Sephadex G-25 previously equilibrated with $0.05 \mathrm{~m}$ potassium phosphate buffer, $\mathrm{pH} 7.0$, containing $10^{-3} \mathrm{M}$ dithiothreitol and $10^{-4} \mathrm{M}$ EDTA. Active fractions on the association of PLP were combined and the protein content was determined colorimetrically.

Preparation of holoaromatic $\mathrm{L}$-amino acid decarboxylase. The apoenzyme was dissolved in a minimum amount of $0.05 \mathrm{M}$ potassium phosphate buffer, $\mathrm{pH} 7.0$, containing $10^{-4} \mathrm{M}$ PLP, $10^{-8} \mathrm{M}$ dithiothreitol and $10^{-4} \mathrm{M}$ EDTA, and dialyzed at $5^{\circ} \mathrm{C}$ for $48 \mathrm{hr}$ against three changes of the same buffer.

Determination of molecular weight. The molecular weight of the aromatic L-amino acid decarboxylase and that of the subunit were determined by gel filtration and SDS disc gel electrophoresis according to the method described in the previous paper. ${ }^{1)}$

Spectrophotometric measurements. Spectrophotometric measurements were performed with a Hitachi model 124 double beam recording spectrophotometer.

\section{RESULTS}

\section{PLP Requirement}

The crystalline enzyme preparation showed

\section{Table I. Effects of Vitamin B 6 Derivatives and Pyruvate on the INACTIVE Form OF ENZYME}

The reaction was carried out at $30^{\circ} \mathrm{C}$ for $30 \mathrm{~min}$ in a reaction mixture containing $1.5 \mu \mathrm{g}$ of the inactive form of enzyme dialyzed overnight against $0.05 \mathrm{M}$ potassium phosphate buffer, $\mathrm{pH} 7.0$, containing $10^{-3} \mathrm{M}$ dithiothreitol and $10^{-4} \mathrm{M}$ EDTA, $4 \mu \mathrm{mol}$ of L-tryptophan, $50 \mu \mathrm{mol}$ of $\mathrm{NH}_{4} \mathrm{OH}-\mathrm{NH}_{4} \mathrm{Cl}$ buffer, $\mathrm{pH} 9.0$, and $0.2 \mu \mathrm{mol}$ of each vitamin $\mathrm{B}_{6}$ derivative and pyruvate as indicated, in a total volume of $0.4 \mathrm{ml}$.

The relative reaction rate using the holoenzyme is 100 . The amount of tryptamine formed from L-tryptophan was determined by the method described in the text.

\begin{tabular}{lc}
\hline \multicolumn{1}{c}{ Coenzyme } & $\begin{array}{c}\text { Relative } \\
\text { rate }(\%)\end{array}$ \\
\hline None & 0 \\
Pyridoxal & 0 \\
PLP & 92 \\
Pyridoxamine & 0 \\
Pyridoxamine 5'-phosphate & 0 \\
Pyridoxine & 0 \\
Pyridoxine 5'-phosphate & 0 \\
Pyruvate & 0 \\
\hline
\end{tabular}

negligible activity after dialysis against $0.05 \mathrm{M}$ potassium phosphate buffer, $\mathrm{pH} 7.0$, without PLP. Using this inactive enzyme preparation, reconstitution was examined in the presence of vitamin $B_{6}$ derivatives or pyruvate. As shown in Table I, enzyme activity was restored by the

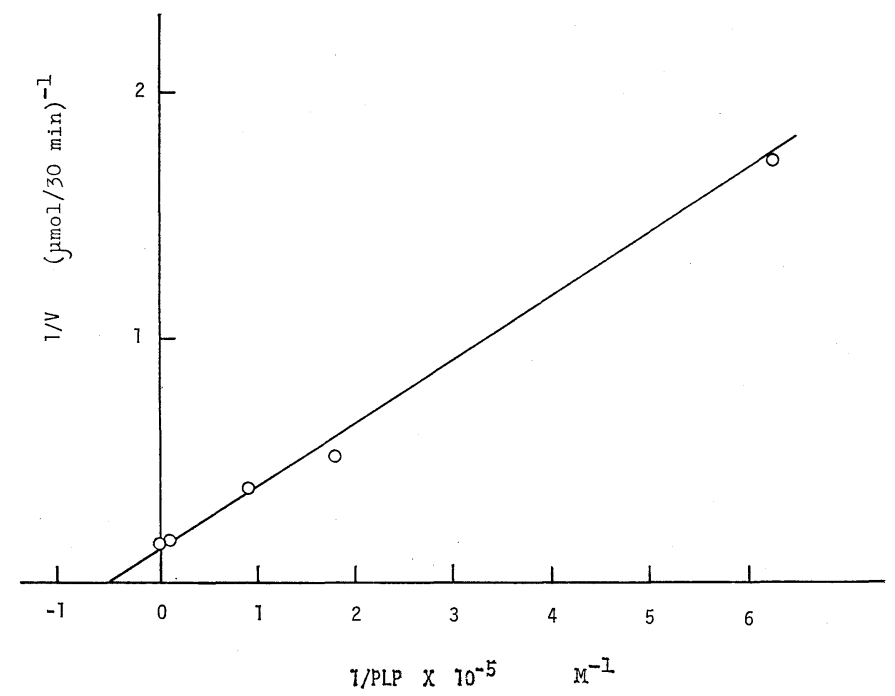

FIG. 1. Effect of PLP Concentration on Aromatic L-Amino Acid Decarboxylase Activity.

The crystalline enzyme was dialyzed before use against $0.05 \mathrm{~m}$ potassium phosphate buffer, $\mathrm{pH} 7.0$, containing $10^{-3} \mathrm{M}$ dithiothreitol and $10^{-4} \mathrm{M}$ EDTA. The reaction was carried out at $30^{\circ} \mathrm{C}$ for $30 \mathrm{~min}$ in a reaction mixture containing $1.0 \mu \mathrm{g}$ of the enzyme, $20 \mu \mathrm{mol}$ of L-tryptophan, $250 \mu \mathrm{mol}$ of $\mathrm{NH}_{4} \mathrm{OH}-\mathrm{NH}_{4} \mathrm{Cl}$

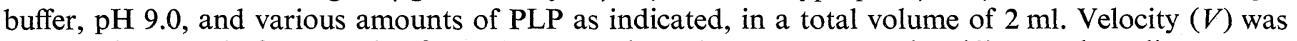
expressed as $\mu \mathrm{mol}$ of tryptamine formed per $30 \mathrm{~min}$ and PLP concentration $(S)$ as mol per liter. 
addition of PLP, but not by pyridoxamine $5^{\prime}$ phosphate or pyruvate.

Using the inactive enzyme preparation, the effect of PLP concentration on the rate of tryptamine formation from L-tryptophan was plotted according to the method of Lineweaver and Burk (Fig. 1.). The concentration of PLP required in the assay mixture to obtain the halfmaximum rate of tryptamine formation from tryptophan $\left(K_{\mathrm{PLP}}\right)$ was calculated to be $2.2 \times$ $10^{-5} \mathrm{M}$.

The apoenzyme prepared as described in Materials AND Methods was inactive in the absence of PLP and retained its full activity on association with the coenzyme.

\section{Absorption spectrum of the enzyme}

The crystalline enzyme preparation showed absorption at $340 \mathrm{~nm}$ (Curve B, Fig. 2) after dialysis against $0.05 \mathrm{M}$ potassium phosphate buffer, pH 7.0. For measurement of the absorption spectrum, the holoenzyme was obtained by dialysis of the crystalline enzyme against the same buffer containing $10^{-4} \mathrm{M}$ PLP, $10^{-3} \mathrm{M}$ dithiothreitol and $10^{-4} \mathrm{M}$ EDTA. The holoenzyme exhibited absorption at $415 \mathrm{~nm}$ besides that at $340 \mathrm{~nm}$ (Curve A, Fig. 2). Molecular absorbance coefficients at 280, 340 and $415 \mathrm{~nm}$ at $\mathrm{pH} 7.0$ were $121,000,9,700$ and

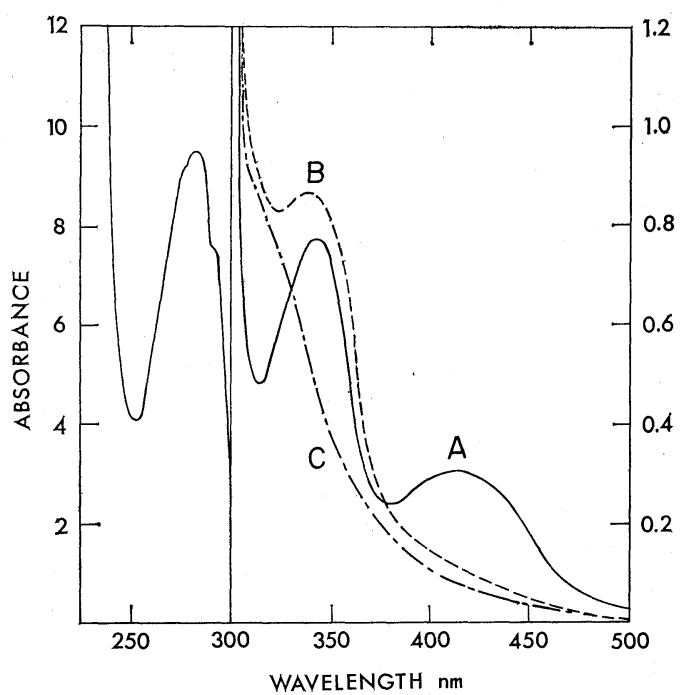

FIG. 2. Absorption Spectra of Aromatic L-Amino Acid Decarboxylase in the Presence and Absence of PLP.

The enzyme concentration was $8.0 \mathrm{mg} / \mathrm{ml}$.

Spectrum A: Enzyme dialyzed against $0.05 \mathrm{M}$ potassium phosphate buffer, $\mathrm{pH} 7.0$, containing $10^{-4} \mathrm{M}$ PLP, $10^{-3} \mathrm{M}$ dithiothreitol and $10^{-4} \mathrm{M}$ EDTA. The spectrum was read against a blank containing the dialysis buffer. Spectrum B: Enzyme dialyzed against the buffer, used for Spectrum A, without PLP. The spectrum was read against the dialysis buffer.

Spectrum C: Apoenzyme was prepared as described in MATERIALS AND METHOD, and the spectrum was read against $0.05 \mathrm{M}$ potassium phosphate buffer containing $10^{-4} \mathrm{M}$ PLP, $10^{-3} \mathrm{M}$ dithiothreitol and $10^{-4} \mathrm{M}$ EDTA.

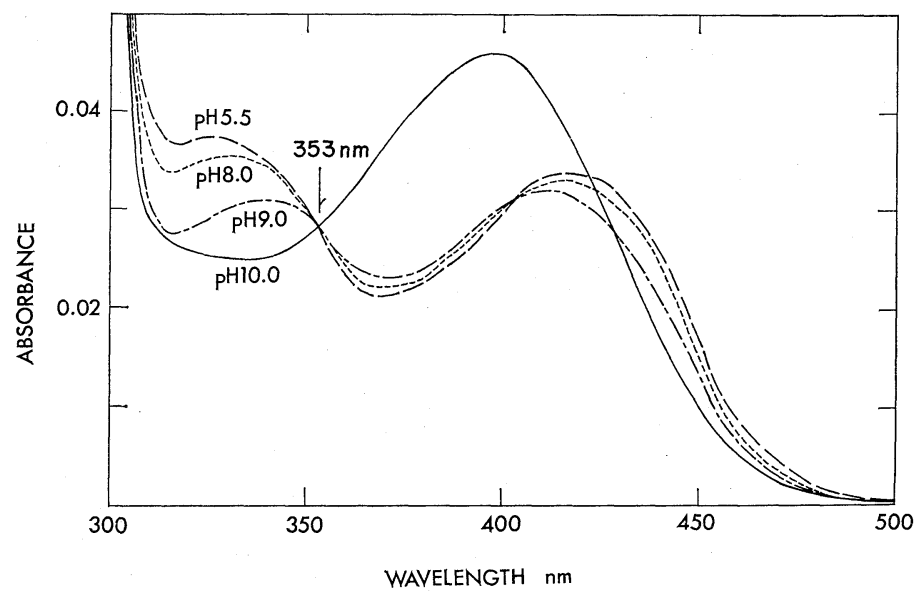

FIG. 3. Effect of $\mathrm{pH}$ on the Spectrum of Holoaromatic L-Amino Acid Decarboxylase.

The spectra were taken with solutions containing $0.5 \mathrm{mg}$ of the holoenzyme in $1 \mathrm{ml}$ of $0.12 \mathrm{M}$ potassium phosphate buffer ( $\mathrm{pH} 5.5$ ) and $0.12 \mathrm{M} \mathrm{NH}_{4} \mathrm{OH}-\mathrm{NH}_{4} \mathrm{Cl}$ buffer ( $\mathrm{pH} 8.0$ to 10.0) containing $2.5 \times 10^{-5} \mathrm{M}$ PLP, respectively. The spectra of these solutions were read against a blank containing the same buffer. 
3,800 , respectively. On varying the $\mathrm{pH}$ from 5.5 to 9.0 , a small but pronounced decrease in absorbance both at 340 and $415 \mathrm{~nm}$ and an increase at $370 \mathrm{~nm}$ were observed in the spectrum of the holoenzyme (Fig. 3). The apoenzyme, prepared by dialysis against phosphate buffer containing 3,4-dihydroxyphenyl-Lalanine as described in MATERIALS AND Methods, did not show any appreciable absorbance at 340 or at $415 \mathrm{~nm}$ (Curve C, Fig. 2). On association with PLP, the pronounced absorptions appeared at 340 and $415 \mathrm{~nm}$ which were quite the same as those of the holoenzyme (Curve A, Fig. 2).

\section{Amount of PLP bound}

The amount of PLP bound by the apoenzyme was determined after dialysis of the enzyme against $0.05 \mathrm{M}$ potassium phosphate buffer, $\mathrm{pH} \quad 7.0$, containing $10^{-4} \mathrm{M}$ PLP, $10^{-3} \mathrm{M}$ dithiothreitol and $10^{-4} \mathrm{M}$ EDTA. After $48 \mathrm{hr}$ at $5^{\circ} \mathrm{C}$ when the control experiment without protein showed complete equilibrium, the concentrations of PLP inside and outside the dialysis tube were determined. An excess amount of PLP found inside the visking tube corresponded to $2 \mathrm{~mol}$ of PLP per mol of enzyme.

The crystalline preparation of the enzyme, the inactive form, was found to contain $1 \mathrm{~mol}$ of PLP per mol of enzyme.
The amount of PLP bound to the apoenzyme prepared in the presence of $0.02 \mathrm{M} 3$,4-dihydroxyphenyl-L-alanine as described in MATERIALS AND METHODS was determined to be zero mol per mol of enzyme.

The results described above indicate the existence of three forms of aromatic-L-amino acid decarboxylase from $M$. percitreus, i.e. holoenzyme, semiapoenzyme and apoenzyme. The properties of the three forms of the enzyme are summarized in Table II.

Molecular weights of the subunits were determined by SDS-disc gel electrophoresis as described in the previous paper. ${ }^{1)}$ Every form of the enzyme showed the same mobility on electrophoresis.

The $K s$ value of the semiapoenzyme was determined from the increase of the absorption at $415 \mathrm{~nm}$ on association with PLP. The value was roughly coincident with the $K_{\mathrm{PLP}}$ value.

\section{DISCUSSION}

Crystalline aromatic L-amino acid decarboxylase prepared from the cell extract of $M$. percitreus was inactive in the absence of PLP and contained one mol of cofactor per mol of enzyme. Thus the inactive crystalline preparation can be regarded as a "semiapoenzyme", which was reported by Soda et al.

Table II. Properties of Holo-, Semiapo- And Apo-forms of Constitutive Aromatic L-Amino AcID DeCARBoXYlaSE From $M$. percitreus

\begin{tabular}{|c|c|c|c|}
\hline \multirow{2}{*}{ Properties } & \multicolumn{3}{|c|}{ Form of enzyme } \\
\hline & Holoenzyme & Semiapoenzyme & Apoenzyme \\
\hline Molecular weight & 102,000 & 102,000 & 103,000 \\
\hline$\lambda_{\max }$ and molecular absorption $\mathrm{I}$ & $280 \mathrm{~nm}(121,000)$ & $280 \mathrm{~nm}(121,000)$ & $280 \mathrm{~nm}(121,000)$ \\
\hline \multirow[t]{3}{*}{ coefficients at $\mathrm{pH} 7.0 \quad$ II } & $340 \mathrm{~nm}(9,700)$ & $340 \mathrm{~nm}(11,000)$ & - \\
\hline & $415 \mathrm{~nm}(3,800)$ & - & - \\
\hline & 2.5 & 7.8 & 6.1 \\
\hline PLP content $\mathrm{mol} / \mathrm{mol}$ of the enzyme & 2 & 1 & 0 \\
\hline \multirow[t]{2}{*}{ Number of subunits } & 2 & 2 & 2 \\
\hline & (Identical) & (Identical) & (Identical) \\
\hline$K_{\mathrm{PLP}}$ values of PLP for the enzyme & $2.2 \times 10^{-5} \mathrm{M}$ & $2.2 \times 10^{-5} \mathrm{M}$ & $2.5 \times 10^{-5} \mathrm{M}$ \\
\hline $\begin{array}{l}K s \text { values between PLP and the } \\
\text { enzyme }\end{array}$ & $2.3 \times 10^{-5} \mathrm{M}$ & $1.8 \times 10^{-5} \mathrm{M}$ & Not determined \\
\hline Enzyme activity & Active & Inactive & Inactive \\
\hline
\end{tabular}


for L-lysine $\varepsilon$-aminotransferase ${ }^{5}$ for the first time.

The removal of PLP from the enzyme during the crystallization was observed as a pronounced decrease in the yellow color of the protein on addition of ammonium sulfate. A drastic color change of the holoenzyme was observed when it was dissolved in $0.12 \mathrm{M} \mathrm{NH}_{4} \mathrm{OH}-$ $\mathrm{NH}_{4} \mathrm{Cl}$ buffer, $\mathrm{pH}$ 10. The absorption spectrum showed an increase at $400 \mathrm{~nm}$ alone (Fig. 3). This absorption spectrum was similar to that of an authentic PLP solution at $\mathrm{pH} 10$; i.e. PLP bound to the enzyme seemed to be liberated from the holoenzyme, and the enzyme changed from the holoform to the apoform.

The enzyme consists of two subunits identical in molecular weight and the holoenzyme contains $2 \mathrm{~mol}$ of PLP per mol of enzyme. It is likely that one of the cofactor molecules is easily liberated from the holoenzyme and the other is bound tightly or becomes bound tightly after removal of the other. This semiapoform exhibited an absorption maximum at $340 \mathrm{~nm}$. Some other PLP enzymes, phosphorylase $b^{6)}$ and glutamate decarboxylase of E. coli, ${ }^{7)}$ were reported to have an absorption maximum at $340 \mathrm{~nm}$ only. Semiapoforms of the PLP enzyme were also reported for L-lysine $\varepsilon$ aminotransferase, ${ }^{8)}$ D-amino acid aminotransferase $^{9)}$ and $\omega$-amino transferase. ${ }^{10)}$
These findings are interesting since they might be concerned with regulation of the enzyme activity or might be one of the keys to elucidate the reaction mechanisms of these pyridoxal enzymes.

Acknowledgments. We wish to thank Professer K. Soda, the Institute for Chemical Research, Kyoto University, Kyoto, and Drs. T. Tsunoda, H. Okada, S. Okumura, K. Mitsugi, K. Sano and H. Enei, of the Central Research Laboratories, Ajinomoto Co., Inc., Kawasaki, for their interest and advice during the course of this work.

\section{REFERENCES}

1) H. Nakazawa, H. Kumagai and H. Yamada, Agric. Biol. Chem., 45, 2543 (1981).

2) H. Nakazawa, K. Sano, H. Kumagai and H. Yamada, Agric. Biol. Chem., 41, 2241 (1977).

3) O. H. Lowry, N. J. Rosebrough, A. L. Farr and R. J. Randall, J. Biol. Chem., 193, 265 (1951).

4) E. Adams, Anal. Biochem., 31, 118 (1969).

5) K. Soda and H. Misono, Biochemistry, 7, 4110 (1968).

6) A. B. Kent, E. G. Krebs and E. H. Fischer, $J$. Biol. Chem., 232, 549 (1958).

7) R. Shukuya and G. W. Schwert, J. Biol. Chem., 235, 1653 (1960).

8) H. C. Dunathan, Adv. Enzymol., 35, 79 (1971).

9) K. Yonaha, H. Misono, T. Yamamoto and $\mathrm{K}$. Soda, J. Biol. Chem., 250, 6983 (1975).

10) S. Toyama, H. Misono and K. Soda, Biochim. Biophys. Acta, 523, 75 (1978). 